\title{
Electricity Generation with the Novel 3D Electrode from Swim Wastewater in a Dual-chamber Microbial Fuel Cell
}

\author{
Mei-Feng LAI ${ }^{1}$, Jia-Hong $\operatorname{LIN}^{1}$,a,Ching-Wen LOU ${ }^{2}$ and Ching-Wen LIN ${ }^{3}$ \\ ${ }^{1}$ Department of Fiber and Composite Martials, Feng Chia University, Taichung \\ 40768,Taiwan \\ ${ }^{2}$ Institute of Biomedical Engineering and Materials Science, Central Taiwan University of \\ Science and Technology, Taichung 40601, Taiwan \\ ${ }^{3}$ Department of Fashion Design, Asia University, Taichung 41354, Taiwan \\ ajhlin@fcu.edu.tw ${ }^{1}$
}

\begin{abstract}
The swine wastewater has the characteristics of high concentration of organic matter, suspended solids and more high ammonia nitrogen, odor, complex pollution ingredient and large emissions. Microbial fuel cells (MFC) is an electrochemical and biological systems related to chemical energy into electrical energy. A two-chambered cubic microbial fuel cell was used to evaluate the effect of a novel 3D electrode which made of iron and copper on the electricity generation. The swine wastewater containing total chemical oxygen demand (TCOD) $3300 \pm 300$ $\mathrm{mg} / \mathrm{L}$ was used as the feedstock in anode chamber, and the potassium ferricyanide was used as electron acceptor in cathode chamber. The MFC reactor was incubated with the initial $\mathrm{pH} 7.0$ in a air-shaker with a temperature (ca. $35^{\circ} \mathrm{C}$ ) and $100 \mathrm{rpm}$ in fed-batch mode. A fixed external resistance (R) of $100 \Omega$ was connected between the electrodes and the closed circuit potentials of the MFCs were recorded every $2 \mathrm{~min}$. The results show that using iron $3 \mathrm{D}$ electrode has the peak electricity generation of $176 \mathrm{mV}$ at the first two day and maintained the stable electricity voltage of $110 \mathrm{mV}$ during the $5^{\text {th }}$ to $15^{\text {th }}$ days. The COD removal efficiency could reach $80 \%$. Using copper 3D electrode only can generate the peak electricity of $33.1 \mathrm{mV}$ and stable electricity of $27 \mathrm{mV}$ with the COD removal efficiency of $70 \%$.
\end{abstract}

\section{Introduction}

Environmental pollution and the depletion of global fossil fuels are driving the search of novel, sustainable energy production alternatives. Microbial fuel cells could reduce the organic compounds in the wastewater and produce the bioelectricity simultaneously [1]. The performance of the microbial fuel cell is affected by many factors, such as substrate oxidation, the ability of microbes to transfer electrons to electrode, external resistance,

*Corresponding author: ajhlin@fcu.edu.tw 
proton transfer through membrane and reduction at the cathode. Electrode materials play an important role in the performance (e.g., power output) and cost of microbial fuel cells (MFCs), which use bacteria as the catalysts to oxidize organic (inorganic) matter and convert chemical energy into electricity [2]. The output power depends on the rate of substrate degradation, the rate of electron transfer from the bacteria to the anode, the circuit resistance, the proton mass transfer in the liquid, the performance of the electrode and the external operating conditions and so on. Different electrode materials vary in their physical and chemical properties (e.g., surface area, electric conductivity, and chemical stability), thus, they also vary in their impact on microbial attachment, electron transfer, electrode resistance and the rate of electrode surface reaction. Therefore, it is of great significance to select and develop suitable electrode materials to optimize and promote the performance of MFCs [1]. A good anode material should have the following properties [3]: (a) good electrical conductivity and low resistance; (b) strong biocompatibility; (c) chemical stability and anti-corrosion; (d) large surface area; and (e) appropriate mechanical strength and toughness. Three-dimensional (3D) electrodes can support an increased attachment of bacteria and increase the volumetric power density, which should in theory result in the better performance of the MFC reactor. Therefore, this study aims to evaluate the effect of a novel 3D electrode which made of iron and copper on the electricity generation in a two-chambered cubic microbial fuel cell.

\section{Materials and Methods}

\subsection{Seed inoculums}

The MFC was inoculated with the enriched pig manure which was cultivated in an A two-chambered cubic microbial fuel cell in our laboratory.

\subsection{MFC configuration and experimental conditions}

The cubic two-chamber MFCs consisted of two polycarbonate or poly (methyl methacrylate) halves separated by an Ultrex anion exchange membrane (CMI-7000, Membranes International, Ringwood, NJ). The working volumes of both anode and cathode were $75 \mathrm{~mL}$. Metal electrodes, plate and $3 \mathrm{D}$ electrode $(5.0 \times 6.0 \times 0.3$ or $5.0 \times 6.0 \times 0.6 \mathrm{~cm}$, McMaster-Carr, Aurora, $\mathrm{OH})$ were used in both chambers and they were pretreated as described by Bond and Lovley [4] before and between each MFC run [5]. The metal plate and 3D electrodes were made of Fe fiber (BR50) and $\mathrm{Cu}$ fiber (CI50) (Taiwan special metal mesh Co., Ltd.). The diameter of each fiber is $0.23 \mathrm{~mm}$. The plate electrode is constructed with plain weave method to form a plain net with dimension of $3 \mathrm{~cm} \times 5 \mathrm{~cm}$ (Fig 1a). The 3D electrode was waved with circular knitting method to form a braid then it was entwined in an acrylic plate $(3 \mathrm{~cm} \times 5 \mathrm{~cm}$ ) (Fig 1b). The working surfaces of the plate and 3D electrodes is shown in Table 1. 
(a)

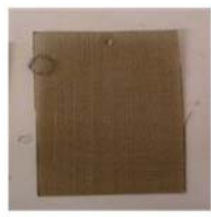

(b)

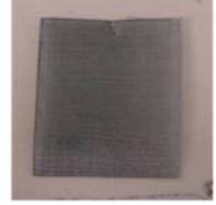

(c)



(d)

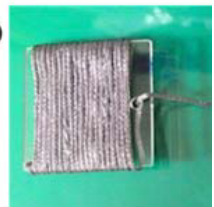

Fig1. Photo of (a) Fe-plate electrode, (b) Cu-plate electrode, (c) Fe-3D electrode and (d) Cu-3D electrode

TABLE 1. PERFORMANCE OF TWO DIFFERENT MFCS WITH PLATE AND 3D AS

ELECTRODE

\begin{tabular}{|c|c|c|}
\hline Item & \multicolumn{2}{|c|}{ working surface $\left(\mathrm{m}^{2}\right)$} \\
\hline Type & $\mathrm{Cu}(\mathrm{g})$ & $\mathrm{Fe}(\mathrm{g})$ \\
\hline plate electrode & 0.073 & 0.054 \\
\hline 3D electrode & 0.278 & 0.208 \\
\hline
\end{tabular}

The pig manure containing total chemical oxygen demand (TCOD) $3300 \pm 300 \mathrm{mg} / \mathrm{L}$ was used as the feedstock in the anode. Potassium permanganate $\left(80 \mathrm{mM}, \mathrm{KMnO}_{4}\right)$ and potassium ferricyanide $\left(50 \mathrm{mM}, \mathrm{K}_{3} \mathrm{Fe}(\mathrm{CN})_{6}\right)$ in phosphate buffer $\left(100 \mathrm{mM} \mathrm{Na} \mathrm{HPO}_{4}, \mathrm{pH}\right.$ 7.0) were used as catholytes.

The MFCs were inoculated $\left(10 \%\right.$, v/v) with the enriched culture and operated at $37^{\circ} \mathrm{C}$ without shaking in fed-batch mode with feed cycle every 2 days. During each feeding, catholyte was replaced by fresh $\mathrm{KMnO}_{4}$ or $\mathrm{K}_{3} \mathrm{Fe}(\mathrm{CN})_{6}$, sample was taken from the anolyte and the sample volume replaced by fresh medium and feed. A fixed external resistance (R) of $100 \Omega$ was connected between the electrodes and the closed circuit potentials of the MFCs were recorded every 5 min with an Agilent 34970A data logger.

\subsection{Analytical method}

APHA Standard Methods [6] was used to determine $\mathrm{pH}$ and chemical oxygen demand (COD) concentration. The power density was calculated according to the equation, $P=I \times$ $V / A$, where $V$ is voltage $(\mathrm{V}), I(\mathrm{I}=\mathrm{V} / \mathrm{R})$ the current $(\mathrm{amp})$, and $A$ the surface area of the anode electrode $\left(\mathrm{m}^{2}\right)$. Polarization characteristics of the MFCs were determined by varying the resistance (between $1 \mathrm{M} \Omega$ and $5 \Omega$ ) by using a variable resistor box from the open circuit voltage stepwise in 5-min intervals. The internal resistances of the MFCs were calculated by the polarization slope method [7]. In a plot of current versus measured voltage, the slope of the linear polarization curve is the internal resistance of the MFC. 


\section{Results and Discussion}

\subsection{Power generation}

Fig 2 reveals the voltage performance using plate electrode and 3D electrode. It shows that using metal electrode could generate the bioelectricity rapidly. The voltage performance (the maximum voltage of $175 \mathrm{mV}$ and average voltage of $75 \mathrm{mV}$ ) were obtained using Fe electrode. Fe-plate electrode has the peak electricity generation of 176 $\mathrm{mV}$ at the first two day and maintained the stable electricity voltage of $110 \mathrm{mV}$ during the 5 th to 15 th days. However, the lower avearge voltages of $15 \mathrm{mV}$ and $25 \mathrm{mV}$ were curried out using $\mathrm{Cu}-3 \mathrm{D}$ electrode and $\mathrm{Cu}$-plate electrode, respectively.



Fig2. Voltage performance using (a) plate electrode and (b) 3D electrode

Fig 3 shows that the higher current dencity was obtained using Fe electrode no matter plate electrode or 3D electrode. The maximal current dencity of $23 \mathrm{~mA} / \mathrm{m}^{2}$ using Fe-plate electrode. This value is higher than the current dencity of $16 \mathrm{~mA} / \mathrm{m}^{2}$ using Fe-3D electrode. Lower cuurent dencities ranged from 0 to $2 \mathrm{~mA} / \mathrm{m}^{2}$ using $\mathrm{Cu}$ electrode. The reason might be that the leachate from $\mathrm{Cu}$ electrode poisons the microorganism in the anode.
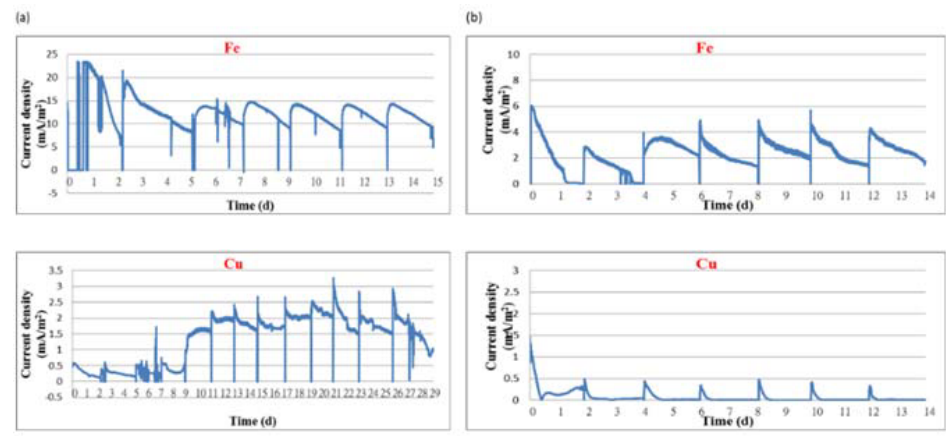

Fig3. Current density using (a) plate electrode (b) 3D electrode

\subsection{Polarization curves and power density curves analysis}

Fig 4 and Table 2 show the analysis results by polarization curves and power density curves at plate electrode and 3D electrode. Muximum power density of $3.95 \mathrm{~mW} / \mathrm{m}^{2}$ and current density of $22.17 \mathrm{~mA} / \mathrm{m}^{2}$ using Fe-plate electrode. 

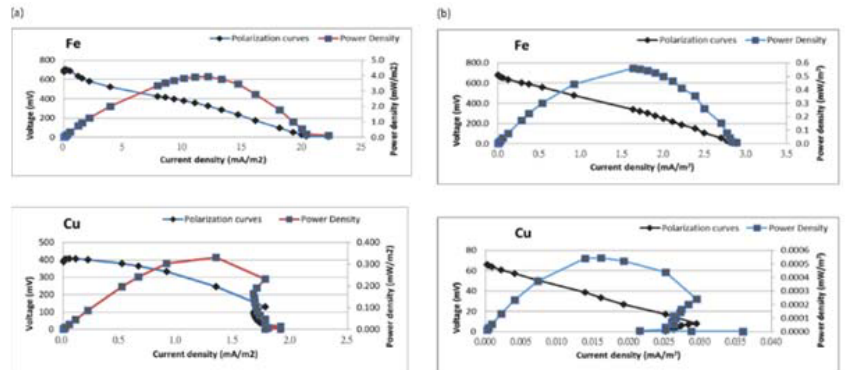

Fig4. Polarization curves and power density curves at (a) plate electrode and (b) 3D electrode

TABLE2. MAXIMUM POWER AND CURRENT DENSITY AT VARIOUS ELECTRODES

\begin{tabular}{|c|c|c|c|}
\hline \multirow{2}{*}{ Electrode type } & Metal type & Power density $\left(\mathrm{mW} / \mathrm{m}^{2}\right)$ & Current density $\left(\mathrm{mA} / \mathrm{m}^{2}\right)$ \\
\hline \multirow{2}{*}{ Plate electrode } & $\mathrm{Cu}$ & 0.33 & 1.91 \\
\cline { 2 - 4 } & $\mathrm{Fe}$ & 3.95 & 22.17 \\
\hline \multirow{2}{*}{ 3D electrode } & $\mathrm{Cu}$ & 0.01 & 0.04 \\
\cline { 2 - 4 } & $\mathrm{Fe}$ & 0.56 & 2.89 \\
\hline
\end{tabular}

COD removal efficiency

The removal of COD from wastewater could reach higher than $90 \%$ using $3 \mathrm{D}$ electrode. The experimental results show that the COD removal efficiency depends on the repeated runs (Fig 5).



Fig5. COD removal using (a) plate electrode and (b) 3D electrode

\section{Conclusions}

Plate and 3D electrodes could be applied in a dual-chamber MFC. Fe electrode shows the higher electricity generation performance compared with $\mathrm{Cu}$ electrode at both plat and 3D electrode. Fe-plate electrode has the peak stable electricity voltage of $110 \mathrm{mV}$. The COD removal efficiency could reach $80 \%$. Using copper 3D electrode only can generate the peak electricity of $33.1 \mathrm{mV}$ and stable electricity of $27 \mathrm{mV}$ with the COD removal efficiency of $70 \%$. 


\section{Acknowledgements}

This study was acknowledged by the professors from green energy development center and department of Fiber and Composite Martials at Feng Chia University, ,Taiwan.

\section{References}

1. M. Zhou, M. Chi, J. Luo, H. He, and T. Jin, "An overview of electrode materials in microbial fuel cells," Journal of Power Sources, vol. 196, pp. 4427-4435, 2011.

2. B. Logan, S. Cheng, V. Watson, and G. Estadt, "Graphite fiber brush anodes for increased power production in air-cathode microbial fuel cells," Environmental science \& technology, vol. 41, pp. 3341-3346, 2007.

3. B. Min, J. Kim, S. Oh, J. M. Regan, and B. E. Logan, "Electricity generation from swine wastewater using microbial fuel cells," Water research, vol. 39, pp. 4961-4968, 2005.

4. D. R. Bond and D. R. Lovley, "Electricity production by Geobacter sulfurreducens attached to electrodes," Applied and environmental microbiology, vol. 69, pp. 1548-1555, 2003.

5. D. Xing, S. Cheng, B. E. Logan, and J. M. Regan, "Isolation of the exoelectrogenic denitrifying bacterium Comamonas denitrificans based on dilution to extinction," Applied microbiology and biotechnology, vol. 85, pp. 1575-1587, 2010.

6. APHA. Standard methods for the examination of water and wastewater. New York: American Public Health Association; 1995.

7. C.-H. Lay, M. E. Kokko, and J. A. Puhakka, "Power generation in fed-batch and continuous up-flow microbial fuel cell from synthetic wastewater," Energy, vol. 91, pp. $235-241,11 / / 2015$. 